\title{
The faithful and the rulers: Calvin's two sermons of 1554 on 1 Timothy 2:1-2
}

\author{
A D Pont \\ Professor Ermeritus: Department of Chruch History (Sec A) \\ University of Pretoria
}

\begin{abstract}
In this study Calvin's two sermons on 1 Timothy 2:1-2 are examined and the contents briefly analyzed. The conclusion is drawn that Calvin is not giving a treatise on the biblical doctrine on princes and rulers, but is addressing the faithful. In doing so, he explains to the congregation their position vis-à-vis the rulers and what Paul's injunctions mean in their situation. It is true preaching as Calvin only expounds the Biblical message as it is found in this text.
\end{abstract}

First of all, then, I urge that petitions, prayers, intercessions, and thanksgivings be offered for all men; for sovereigns and all in high office, that we may lead a tranquil and quiet life in full observance of religion and high standards of morality.

(1 Tm 2:1-2 [NEB])

\section{INTRODUCTION}

Starting on September 16, 1554 Calvin gave his exposition of the Letters to Timothy to the congregation. This eventually became fifty-five sermons. These sermons were preceded by his sermons on the two Letters to the Thessalonians (De Greeff 1989:103). The two sermons on 1 Timothy 2:1-2 were therefore not special sermons but part of his structured preaching programme. In these two sermons he explained to the congregation the Biblical guidelines for their relationship with the magistrates. In these sermons Calvin employs his usual analytical and explanatory-didactical style. Nothing in the contents of the sermons suggests that Calvin is employing the Biblical text to air his differences, at that time, with the magistrates of Geneva.

These sermons on the Letters to Timothy were preceded in 1548 by Calvin's commentaries on them (cf Ioannis Calvini Operae quae supersunt omnia, [Quoted as CO LII:263f]). When Calvin expounded the subject matter of 1 Timothy 2:1-2 in 1554 , it was not the first time he applied his mind to this particular Biblical passage. 
Calvin's treatment of the theme, the faithful and the rulers or magistrates, was rather apposite in 1554. During the fifties Calvin experienced much resistance and opposition from the magistrates who did not share his views. This led Calvin to write a letter of resignation to the Council on July 24, 1553. The Council's obstructionist policies towards Calvin and the other ministers of Geneva was a continual irritation. In Calvin's letter it becomes evident that he had had enough. The Council, however, did not accept his resignation. As Parker pointed out (Parker 1975:116): 'The Libertines wanted a Calvin subservient, not a Calvin martyred by banishment and opposing them from Basel or Zürich'.

Within three weeks of Calvin's attempted resignation, the Servetus episode started. This ended with the triumph of Calvin's vision that it is the task of the magistrates to protect and promote true religion and humanitas in the community (cf Defensio orthodoxae fidei, [Quoted as Johannis Calvini Opera Selecta, 1:260f]). After the Servetus episode the position of Calvin and the ministers gradually became stronger. Early in 1555 the authorities at long last decided that the Church Order of 1541 would be maintained. From that point onwards the influence and authority of the Libertines gradually declined as Calvin's views were accepted and carried through. Thus Calvin's view of the order of the church and of life in Geneva gained general acceptance.

The two sermons on 1 Timothy 2:1-2 were delivered in the period when Calvin experienced strained relations with the magistrates due to their opposition to his views and person. It is evident from the sermons that Calvin did not see this as an opportunity to launch a diatribe against the magistrates. In the sermons there is a balanced exposition of the Biblical text and they contain the usual explanatory, pastoral and didactic elements found in all his sermons. Calvin does, however, make a few excursions in the sermons which are not, prima facie, suggested by the Biblical text. In these he remarks on the task and duty of the rulers and is rather critical of the way in which they carry out their duties. This does suggest that he had the situation of 1554 in mind, and Kingdon's remarks on this point strengthens the surmise (Kingdon 1984:58).

In his second sermon on the same text (1 Tm 2:1-2) Calvin gives an exposition of the Biblical criterion by which the rulers are to be judged. His point of view is very clear when he says (Sermo 12, CO LIII:141): 'The magistrates must know what judgment will be passed and what terrible vengeance awaits them if they do not perform their duties diligently $i$ e to honour God which means that the true religion has a place among men and is a force in their midst'.

This is a more critical view of the ruler than that found in Institutes IV 20.6. It probably coincides with Calvin's remark from 1548 that a minister must have two voices, one to gather the flock and the other to scare away the wolves (Comm Past Ep 1.296). 
These two sermons of Calvin certainly conform to the requirements for a sermon that he enumerated in his letter to the Duke of Somerset on October 22, 1548 (CO 13.65-77). There Calvin said:

\begin{abstract}
Preaching must not be dull, but lively to teach, to reprimand and to urge to do good .... You know ... how Paul refers to the liveliness which has to characterise the sermons of those who would like to show that they are good and true servants of God. They must not give a show of rethoric so that they will be respected, but the Spirit of God must be heard in their preaching so that the Spirit can act forcefully. All the dangers of which man is afraid cannot hinder the Spirit of God in its freedom to act through them whom God, in His grace, has appointed to build the church in faith.
\end{abstract}

Preaching, for Calvin, is the organum Dei ad salutem (CO 46.16) and the purpose of preaching is to build up the faithful and the church in faith. His view is neatly expressed in Institutes III 23.13: 'Let preaching, then, take its course that it may lead men to faith and hold them fast in perseverance with continuing profit'. Therefore Calvin in these two sermons emphasized the duty of the faithful to be true to their faith and their obedience to God. God's care and trust in His promises are the two points of support for the faithful and, in comparison with them, the rulers and all their powers are no longer a decisive factor (cf Oberman 1994:114).

\title{
2. A SHORT SUMMARY OF CALVIN'S TWO SERMONS ON 1 TIMOTHY 2:1-2
}

When the contents of the two sermons are examined, it is immediately obvious that Calvin's exegesis of vs 1-2 is influenced by vs $2-4$. The petitions, prayers and intercessions '... for sovereigns and all in high office are qualified by the fact that it is God's will ... that all men should find salvation and come to know the truth'. Coupled to Calvin's doctrine of obedience this means that the prayers, petitions and intercessions for sovereigns and all in high office are mandatory, not because the rulers are so special but because God's will is: '... that all men should find salvation'. This obedience to God is for Calvin '.. the basis and fountainhead of all virtue' (Sermon 12, CO LIII:145). It is of major importance that all men will hear the Word of God so clearly that they will become dependant on that Word and will live according to the dictates of 
the Word (Sermo 12, CO LIII:16). Here Calvin touches on the coherence between the justification by faith and the life of gratitude and obedience which is the result of justification. Calvin emphasises the point that the faithful must be obedient to God and that they relegate their own preferences to the background.

The broad outline that Calvin draws of the Christian community correlates with the first blueprint he drew in the Institutes of 1536 (Inst 1536:VI). It is the community of the faithful governed by the two servants of God: the church and the civil ruler, who both obey God in everything and thus live and work within the order that God has given to man. The two pillars of obedience to God and His Word and the existence within the order of God are detailed in these sermons. In the first place by the injunction that petitions, prayers, intercessions and thanksgivings be offered for all men, for sovereigns and all in high office. Here Calvin argues that to pray with the correct contents, the faithful must know the will of God. To know the will of God, the faithful must understand God's message because only then will the faithful be able to '... direct their prayers according to the will of God and to rely completely on his promises (cf Inst 1559 III.20.3). Reliance on God's promises and the effectiveness of correct prayers are underscored in these two sermons.

Calvin exhorts the faithful to pray for the church and for all men in their private and other prayers. In this regard the church, which is not mentioned in the Biblical text, is of the first importance because the church is the Body of Christ where the faithful live together like brothers (Sermo 11, CO LIII:127).

This correlates with Calvin's interest in and concern for the church and the order that has to prevail in the community of saints (cf Calvin's Catechism 1545, Q 99). It becomes evident that the magistrate and public life are not Calvin's first concern in this sermon. The magistrates are only important in so far they either help or hinder the church in the performance of its task (Leith 1978:202). Prayer and intercession for all men, for the church and for sovereigns and all in high office is of importance because God expects the faithful to serve one another. In the performance of this task, prayer is an important instrument (Sermo 11, CO LIII:129).

It is in this context that Calvin explains the prayers and intercessions for sovereigns and all in high office. As in his Commentary on Timothy, Calvin points out that it is not always so easy to pray for rulers. He mentions that in the New Testament the rulers and magistrates were 'enemies of the gospel' (Sermo 11 LIII:130). Notwithstanding the attitude of the rulers, Calvin insists that the faithful should pray for the rulers because the prayer is a prayer that God will maintain the polity He ordained for man. Even if the rulers conduct themselves like avowed enemies of God, the faithful 
can be content in their knowledge that these rulers cannot undo what God has instituted. It is in this context that Calvin states that God gives to a community or people such rulers as they truly deserve (Sermo 11, CO LIII:131. Then Calvin states (Sermo 11, CO LIII:132): ' $\ldots$ that we, in general, have the opinion that the rulers or magistrates should be of great value to us because this polity was established in the world. For that reason we have to pray for all men who are appointed in high office'.

Then Calvin stresses that the faithful should pray for the Kingdom of Christ because they are primarily citizens of that kingdom. The kingdoms of this world are, if they perform their task and duty correctly, no more than a shadow and likeness (comme figure et image) of Christ's Kingdom (Sermo 11, CO LIII:132).

Only in the Kingdom of Christ do we find the perfect order and polity. But because the rulers and magistrates of this world must also obey Christ, the faithful should pray for them because it is God's will '... that all men should find salvation and come to know the truth'. The order and polity that God has given together with His promises are of greater importance than that everything should develop according to the human expectations of the faithful. Therefore Calvin condemns those who would subvert the God-given order so that no ruler, sovereign or magistrate can exist in this world (Sermo 11, CO LIII:133). Such people reject an institution of God and in doing so become enemies of God.

In the second sermon, Calvin deals with the rulers and all in high office '... that we may lead a tranquil and quiet life in full observance of religion and high standards of morality'. Calvin points out that the first task and duty of the ruler is to maintain the honour of God and, at the same time, he is bound to protect the humanitas in the community. In his treatment of this double duty Calvin is rather critical of the failure of rulers and magistrates to perform this task. He admonishes all rulers that they will not escape the judgment of God if they neglect their duty (Sermo 12, CO LIII:140).

Although it may happen that rulers or magistrates neglect their duty, Calvin insists that the faithful should pray for them and obey them because obedience is better than sacrifice (Sermo 12, CO LIII:146). The faithful must know what God expects of them and, in accordance with this knowledge, they must pray and wait for the fulfilment of God's promises (Sermo 12, CO LIII:146). The order and polity that God established may not be overturned because without that order man will be and live like an animal. Whenever a ruler or a magistrate rules according to God's Word, the faithful must thank God and pray that God will maintain him because such a government is in accordance with the Kingdom of Christ. In all other cases the faithful must take comfort from the knowledge that the sovereignty of Christ cannot be diminished by earthly rulers. 


\section{SOME REMARKS}

These two sermons are definitely not an exhaustive or a complete discussion and exposition of Calvin's view on the relation between the faithful and their rulers. They are no more than an explication of the Biblical text for his congregation. The impression created by these sermons is that Calvin is not so much concerned with the magistrates and their duties but that the whole emphasis is on the faithful, their task and duty. Therefore the weight of the sermons is placed on the exhortation that the faithful must live in this world in obedience to God. In the fulfilment of his duty, the ruler may be a hindrance or a help, but this should not distract the faithful from their steadfast obedience to God.

Calvin treats the role that rulers have in a society extensively in the editions of his Institutes from 1536 onwards and also touches on the theme in his Commentaries on Romans and Daniel. The sermons on 1 Timothy 2:1-1 are pastoral and encouraging expositions in which Calvin shows that the faithful are, in the first place, citizens of the Kingdom of Christ and that the goal of a Christian's life is in God's eternity.

It may be noted that this emphasis does not occur in the Institutes or the Commentary on Timothy, nor is the description of the lawful government as a shadow or a likeness of the government of Christ found there. This is probably because the Institutes has a more dogmatic-didactic emphasis while in his sermons Calvin addresses the congregation in Geneva and deals with their task and duty in the world. In the sermons Calvin is concerned about the faithful and the rulers are mentioned because they occur in the world in which the faithful live.

In his second sermon on 1 Timothy 2:1-2 Calvin explains that the rulers have been instituted by God and that they too have received a ministerium from God. They have a task and a duty to perform. When Calvin summarises the tasks of the rulers (Sermo 12, CO LIII:140) he mentions that they have to maintain peace in the society, to see that everyone has what he deserves, that nobody is harassed or wronged, that everybody is treated lawfully and fairly by those in authority, that nobody is favoured to the detriment of others, that hate and revenge do not prevail, that honesty and moderation are maintained, that dissipation and lawlessness are curbed, that no injustice is allowed and that all people are kept in check. Above all, the rulers must see to it that the reverence for God, the pure and correct religion, is maintained. Here Calvin enumerates the duties of the rulers according to the second table of the Ten Commandments. This exposition, although fairly short, is probably clearer than that found in the Institutes IV.20.9. Calvin stresses that it is the duty of the magistrates to restrain with all their powers those who (Sermo 12, CO LIII:140). ‘... proclaim errors and false teaching ... and furthermore all fanatics, who being led by the spirit of Satan, propagate that complete freedom should in these times be given to all who want to disrupt the unity of the faith and the peace of the church'. 
In these words the congregation probably heard a reference to Servetus. In any case, Calvin justifies his instruction by describing the rulers as 'substitutes of God' (lieutenans de Dieu) (Sermo 12, CO LIII:138, 140). In the Institutes the rulers are usually typified as 'servants' (Inst IV.20.6) but here they are 'substitutes'. It is not clear from the sermon itself why Calvin here departs from his usual description. It could be because Calvin then, rather sharply, reprimands the magistrates because they do not fulfil their commission. Calvin states (Sermo 12, CO LIII:140): 'They allow God's glory to be held in contempt, that His name is defamed and His service is subjected to all sorts of abuse so that disorder and confusion prevails everywhere. Is that not offensive ungratefulness?'

Then again Calvin comforts the faithful by proclaiming that Christ's Kingdom and rule are not dependant on the rulers of this world but by far surpasses their rule.

In the second sermon, the emphasis of the argument is also on the task and duty of the faithful and not so much on those who occupy high office. Calvin repeats that the faithful must live in obedience to God, notwithstanding rulers and magistrates. It seems as if Calvin sees the magistrates as part of the afflictions and trials that the faithful have to endure in this world (Sermo 11, CO LIII:125). Even if that is so, Calvin insists that the faithful should pray for all rulers. He reiterates that the faithful may be comforted and sustained by the fact that if they pray to God in the name of Jesus Christ, their prayers will be neither futile nor in vain.

\section{CONCLUDING REMARKS}

It may be said that in these two sermons we meet a 'different' Calvin from the writer of the Institutes, the pamphlets, the polemical treatises and the commentaries. One can speculate on the possibility that Calvin the preacher-pastor is the 'real' Calvin because the sermons represent the major part of his life's work. While the research on Calvin's sermons has not yet reached the same intensity as the study of his other work, this is an interesting idea to reflect on. On the other hand, the difference of audience alone will probably not reveal a 'new' Calvin but, at the most, give us an insight into the pastoral emphasis in Calvin's work. Coupled with the new knowledge of Calvin's pastoral work in the Consistoire, the study of the sermons will enable researchers to draw a more complete picture of the great reformer.

It is, however, rather special to listen to Calvin in his pulpit, where he is preaching to the congregation, exhorting them to be steadfast and encouraging them to continue in their service of God and man. This goes a long way to explain the difference in accent when these two sermons are compared to the Commentary on the same two verses. 
If we look at the sermons, it is clear that Calvin's first objective is to strengthen the congregation in their faith and love of God and at the same time to teach them respect for and acceptance of the order God ordained in this world. Therefore Calvin emphasizes that the main task of the faithful is prayer (Sermo 11, CO LIII:126). It is the Holy Spirit who encourages the faithful to persevere in their prayers for all men because this is the most significant encouragement and support they can give to those who need help (Sermo 11, CO LIII:128). It is within this broad framework that Calvin places prayer for the rulers. The exposition of the position of the rulers and everything pertaining to their task is, however, not the main object of these sermons. Calvin emphasized that the faithful must pray for the rulers because when they fall short of what is expected of them, God's judgment will be severe. And, as Calvin explains it, the final reason for these prayers is that it is God's will that all men shall find salvation.

It is remarkable that Calvin, notwithstanding the rather difficult circumstances for him in Geneva at the time and his criticism of those in authority, still maintained a balance in his exposition of Scripture. In this way he fulfills his duty to explain Scripture in such a way that the congregation will hear not only the true meaning of the Biblical text but also the viva vox evangelii.

\section{Works consulted}

Barth, P, Niesel, G \& Scheurner D (eds), 1926. Johannis Calvini Opera Selecta. München.

Baum, G, Cunitz, E \& Reuss, E (eds) 1895. Ioannis Calvini Operae quae supersunt omnia. Brunsvigae: C A Schwetschke et filium.

De Greeff, W 1989. Johannes Calvijn: Zijn werk en geschriften. Kampen: Uitgeverij De Groot Goudriaan.

Leith, J H 1978. An Introduction to the Reformed tradition. Atlanta: John Knox Press.

Kingdon, R 1984. Calvin and the government of Geneva, in Neuser, W (ed), Calvinus Ecclesiae Genevensis Custos, 49-68. Frankfurt a M: Verlag Peter Lang.

Oberman, H 1994. Initia Calvini: The matrix of Calvin's reformation, in Neuser, W (ed), Calvinus Sacrae Scripturae Professor, 113-154. Grand Rapids: Wm B Eerdmans Publishing Co. 